\title{
Conceptions about environment and environmental education by teachers from rural schools in Bogotá - Colombia
}

\author{
Carlos Julio Galvis-Riaño \\ Francisco Javier Perales-Palacios \\ Yolanda Ladino-Ospina
}

${ }^{\mathrm{I}}$ Doctorate in Education Sciences, University of Granada Granada-Spain

D II Department of Didactics of Experimental Sciences, University of Granada

Granada-Spain

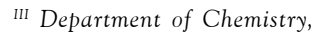
National Pedagogical University Bogotá - Colombia
Abstract: The concepts of Environment and Environmental Education (EE) were characterized by a sample of teachers from four rural schools in Bogotá. EE currents were regarded as a theoretical reference (Sauvé, 2010), an aspect considered for the methodology and analysis of information. Interviews were conducted by applying the Multiple Item Classification and using environmental news images. The aim was for teachers to make classifications according to their knowledge and experiences. Based on their own descriptions, the classifications were categorized pursuant to EE currents. The information obtained made it possible to establish that educators have different ways of addressing the environmental issue and associating it with their educational practice. There was a strong tendency to assume that the Environment and $\mathrm{EE}$ are a biological and conservationist issue, basic aspects for life in the countryside.

Keywords: Environmental education, teacher conceptions, environment, Multiple Item Classification.

São Paulo. Vol. 23, 2020

Original Article

DOI: http://dx.doi.org/10.1590/1809-4422asoc20180200r1vu2020L4AO 


\section{Introduction}

One of the issues that has awoken the greatest controversy in today's society is that related to the change in the environmental conditions of the planet, and the increasingly fragile and unbalanced relationship between man and nature. Fifty years after the declaration of the "ecological crisis" in the world, it is clear that the actions and measures to counter this situation have not yet been effective enough, and on the contrary, the path of crisis has been wrongly pursued, increasing socio-environmental problems, exerting an irrational use of nature and transforming at will the spaces and scenarios required for human survival.

After proclaiming the ecological crisis, a new subject of study emerges, to wit, "the Environment", whose initial approach was mainly based on believing that it specifically referred to the body of physicochemical and biological elements in constant interaction in nature, which has changed to over these years since it went from the purely ecological approach to understanding the concept as an existing relationship between the natural and the sociocultural affairs of human life in its various manifestations, i.e., (political, economic, historical, among others), and in a mutual interaction.

Thus, referring to the environment nowadays equals referring to a cross-sectional multicultural concept in nature, which arises from the various social debates with regards to diversity, quality of life, territory and human development. Addressing the dimension of the environment has meant recognizing that there are thoughts, representations and ways of conceiving it. The concept of environment has been built at the core of societies; it is defined and transformed in a constant interrelationship between symbolic processes and everyday practices. In this sense, the environment cannot be interpreted simply as a matter pertaining to natural processes, but to biosocial processes where man is its main stakeholder.

Unfortunately, this concept has been given indiscriminate and speculative use on account of misconceptions that differ from scientific knowledge. The diversity in opinions, approaches and stands has led to biased and contradictory interpretations in themselves, an aspect that has affected collective imaginaries and individual representations.

The issue of establishing what would be the most accurate concept to define the environment and, therefore, determine the best way to work for it, has led the world's socio-cultural systems to create their own or unique criteria to address them in a dimension of problems and needs. A clear example is that of educational systems, with a special emphasis on their processes, where the main stakeholders (students and teachers) assume and address their responsibility and participation in environmental matters depending on government educational policies and syllabus models in their institutions.

Thus, it becomes necessary to reflect on what is the role of the teacher in this process, what the role this educational stakeholder play in teaching about EE based on imposed models, and not on his own criteria and knowledge. The ideas of environment and class EE is still held in the cultural structures of modern societies, a situation that is recurrent in developing cultural and educational systems such as those in Latin America, and especially Colombia, where training and education processes in schools still cultivate 
the idea that environment and EE are an issue of the natural sciences, and that their approach must be from a conservationist and protectionist perspective (environmental problem-solutions), possibly generating in the students and teachers themselves an erroneous, fragmented, superficial view of the environment impregnated with clichés and obtained mainly through the media (PERALES, 2010), thereby relegating socio-cultural elements in principle.

Considering the above, it is proposed that the objective of this study be a characterization of the conceptions of environment and $\mathrm{EE}$ by teachers in educational institutions of Bogotá, making a special emphasis on rural educational centers. For the methodological development and subsequent analysis of information, we take as a theoretical reference the EE currents proposed by Sauvé (2010), with which we identify certain trends and thoughts within the environmental framework associated with the cultural and social contexts of rural regions in Colombia.

\subsection{Background}

The scarce research carried out on EE in the rural context shows the importance of analyzing in depth the models, currents, methods and strategies that are frequently used in teaching and learning. For example, BARRIOS (2009) and LEON et al. (2010) identified some factors recognized today to achieve rural EE in accordance with the requirements of its stakeholders, confirming the need to delve deeper and expand on the conceptual approach and strategic design (promoted through environmental educational guidelines). The aforementioned authors agree that the problem is not inherent to EE practices, but lies in the very conception of environment matters, generalizing that in most cases these conceptions are contradictory and sometimes opposite. The concept of environment as a socio-natural construct and $\mathrm{EE}$ as a teaching-learning process to achieve it are regarded nowadays as one of the most relevant topics to form responsible and committed citizens. However, its processing at the different levels of the education system attests to a standpoint very distant from the desirable way of understanding it. In most cases, it is presented as a sum of independent, fragmented and decontextualized components.

FLOGAITIS and AGELIDOU (2003) inquired about the ideas on nature and environment through a word association questionnaire in a sample of early childhood education teachers. Their results showed that ideas about the environment were naive and utopian because they were related with a naturalistic typology, and a considerable percentage even confused nature and environment. Likewise, the training programmes received did not seem to influence these conceptions.

MICHAEL, STAMOU and STAMOU (2007) evaluated various preconceptions of practicing Primary Education teachers about some environmental concepts and their emerging nature image through a closed questionnaire. Their results show erroneous preconceptions from the scientific point of view and a "romantic" view of the nature that attributes environmental problems to the human factor exclusively. 
MUÑOZ et al. (2009) conducted a study using a Likert questionnaire to compare teachers' conceptions about nature and environment in 16 countries. From the statistical analysis employed were inferred two main dimensions in the conceptions under investigation: usefulness (anthropocentric) and preservation (naturalist), with the socioeconomic level and the disciplinary training of teachers acting as differentiation factors between countries.

TALERO, UMAÑA and CHAVEZ (2000) developed an analysis model to assess EE conceptions. The function of the model is to identify whether the conceptions are immersed in some of, or why not all, the following approaches: conceptual, philosophical, axiological, pedagogical, didactic and political-legal. According to the authors, these approaches make it is possible to understand the conceptual relationships that influence the thinking of teachers regarding the definition of a conception about environment.

\subsection{Using the image in $\mathrm{EE}$}

In connection with the research described above, the use of the image to highlight people's conceptions on environmental issues has some precedents that we will summarize below:

REZLER et al. (2009) tried to bring to light the conceptions of Elementary students about the preserved and degraded natural environment by asking them to draw both, and this was how they obtained representations of biotic factors, abiotic factors and residues produced by humans. In a similar vein, PEDROZO and DE OLIVEIRA (2015), through a case study, worked with a single image invented by the students regarding the problem of urban waste in Brazil.

In the case of photographic images, works of different kinds have been approached. Thus, through content analysis, SULLIVAN (2008) studied several urban ecosystem photographs contained in textbooks, and learned that such environments are not usually represented as true ecosystems, for are reserved only for natural environments.

Closer to the approach of our study, QUIGLEYA et al. (2014) used photo vignettes to discover teachers' perspectives on the human-nature interaction through discussion groups. The responses were organized around three themes: ecocentric, apathetic and anthropocentric view.

CALAFELL AND BONIL (2014), in a similar vein, address their research with practicing teachers linked to sustainable schools. For this purpose, they use a bank of images that are interpreted through the typology of conceptions proposed by SAUVÉ (2005) thereafter. Their results show low diversity in conceptions about the environment, and those in the cultural (globalizing) and naturalistic sphere predominate, which, in turn, are the ones that manifest a greater degree of complexity.

We also highlight the work of DEMOLY and SANTOS (2018), who used the production of photographs and narratives about them through workshops with students and teachers. The monitoring of their conceptions about EE was carried out through a qualitative analysis throughout the development of these workshops, which evidenced a 
cognitive transformation thereof.

The use and exposure of people to images (external representations) on environmental issues is increasingly widespread and used due to the multiplication of viewing scenarios such as the Internet, television, magazines, newspapers, etc. Images in general are produced and disseminated to account for the transformation of nature and to outline a representation of environmental reality (HOLLMAN, 2011).

\section{Method}

\subsection{Context and Sample}

The research was carried out in four rural schools in Bogotá (Colombia). The institutions are state-owned and provide early childhood care at the preschool and primary basic grades, and to adolescents in the secondary grades.

Teachers linked to these institutions comprise a population of 162 teachers. This research took a representative sample of $30 \%$ of the total, that is, 48 educators ( 25 men and 23 women) from different Primary and Secondary academic areas in each school, using the multiple selection technique. The criteria to select the teachers were that they had one year's or more experience in the institution and that their professional training was attached to any disciplinary field of education.

\subsection{Methodology}

The research is of qualitative nature given that a study was carried out with people in order to learn from their practice and experience, their perceptions and interpretations about their relationship with the concepts of environment and EE. Considering that this is an exploratory work with subjects in their own context, rapid ethnography was chosen as a qualitative research method to search for ex situ information in a short period of time (PARAMO, 2011). A structured interview based on the Multiple Classification of Items -CMI- model was applied as the technique to gather information. This technique is explained below.

\section{CMI-based interview with environmental and EE images}

The CMI interview is a qualitative technique to obtain personalized information that requires an interviewer and interviewee. $\mathrm{CMI}$ is a strategy used to process complex variables collected in a research. As a technique, it allows to explore interactive aspects in the same event using a stimulus (in this case images) and the responses (classifications) caused by such stimulus in several individuals (PACHECO, 1996). It is considered a flexible technique because the data it obtains allow to establish relationships among items, subjects, groups, or a subject's various responses regarding the different classifications depending on the conditions and possibilities that the interviewer (researcher) offers to the interviewee (PACHECO, 1996). CMI asks participants to classify a set of items. For 
this research particularly, the items pertained to a set of images allusive to the topics of environment and $\mathrm{EE}$, which were selected from the multiple graphic expressions (photographs, drawings, paintings, among others) that exist in our social systems to provide a notion of what the environmental dimension means and its approach from natural and cultural perspectives.

Based on the chronology of SAUVÉ (2010) and understanding the importance of encouraging interviewees to classify or group the topic put before them, 24 images alluding to the environment, $\mathrm{EE}$ and the man-environment relationship were picked, which were printed on cardboard in the form of cards (see the list of images and the selection criteria in Table 1).

The interviewing procedure through CMI aims to elucidate personal classification schemes in relation to how teachers represent the object of study, that is, the environment and EE. CMI asks interviewees to classify a set of items, which are the 24 cards with selected images in this case. The image classification criterion for grouping is freely chosen by the study participants, who are allowed to produce the number and types of classifications they desire, as long as they create different ways to group them.

The CMI asks about the concepts the interviewee uses to assign different objects or elements to categories. The subject is then asked to classify the elements (images on cards) into groups so that all elements, in any given group, have something important in common, that sets them apart from other groups of elements. This produces a certain number of groups, which could vary in the number of elements they contain and, logically, the number of groups produced could vary from person to person and from one group of elements to another.

\section{Table 1 - List of images selected and used in the CMI interview}

\begin{tabular}{cll}
$\begin{array}{c}\text { Card } \\
\text { No. }\end{array}$ & \multicolumn{1}{|c}{ Selected image } & \multicolumn{1}{c}{$\begin{array}{c}\text { Selection criteria based on Sauvé's (2004) } \\
\text { EE currents }\end{array}$} \\
1 & Children playing in the field & Eco-education \\
2 & Transgenic foods & Moral - Sustainability \\
3 & Boy looking at a microscope & Scientist - Humanist \\
4 & Hamburger & Moralist \\
\hline 5 & Indigenous community & Ethnographic \\
\hline 6 & Man feeding an animal & Naturist - Eco-education \\
\hline 7 & Windmill & Resources \\
\hline 8 & Campaign to protect the forest & Conservationist \\
\hline 9 & Housing in the countryside & Naturist - Bio-regionalist \\
\hline
\end{tabular}




\begin{tabular}{|c|c|c|}
\hline $\begin{array}{l}\text { Card } \\
\text { No. }\end{array}$ & Selected image & $\begin{array}{c}\text { Selection criteria based on Sauvé's (2004) } \\
\text { EE currents }\end{array}$ \\
\hline 10 & Forest use & Humanist \\
\hline 11 & Shape of an animal with recycling & Sustainability - Holistic \\
\hline 12 & Built landscape & Humanist \\
\hline 13 & Acid Rain Cycle & Critical - Systemic \\
\hline 14 & Sculpture with plants & Holistic - Naturalist \\
\hline 15 & Landscape & Naturist - Systemic \\
\hline 16 & Fish taking garbage out of the sea & Holistic \\
\hline 17 & City with a polluted river & Moralist - Resolutive \\
\hline 18 & Dry Lake & Resolutive \\
\hline 19 & The hands of a child and an adult & Conservationist \\
\hline 20 & Urban agriculture & Praxic - Sustainability \\
\hline 21 & Camp in the desert & Naturist - Holistic \\
\hline 22 & Animal abuse & Critical \\
\hline 23 & Peasant farm & Bio-regionalist \\
\hline 24 & Peasant Woman & Feminist - Ethnographic \\
\hline
\end{tabular}

Source: Authors' own elaboration

Once the interviewee makes the first division or grouping, the same is asked about the criteria used to create the first classification and to give it a name, which is considered the classification category. As it is assumed that different groups of images were created within the classification because of their similarity, affinity or having something in common, the interviewee is asked to give a name to each of the groups (which for research purposes are considered the subcategories), and so on is done the number of times the interviewee divides (categories) and groups images (subcategories).

Once the data from the divisions (categories) and the groups by images (subcategories) of all participants in the interview have been obtained, an analysis matrix supports the review of the most predominating divisions' names, the relationship between images and mots recurrent groupings among the teachers interviewed. The names of the divisions or categories with the highest number in presence or frequency percentage among all participants are those considered to be the dominant categories among the conceptions of teachers.

Given the variety of names that together are very similar, and according to the criteria of each teacher, the researchers choose the most appropriate name to describe 
the concept given by the teachers as a set.

The information from the divisions and groupings of images made by all the teachers interviewed was graphed out by means of a specialized software called HUDAP. This software contains an application called Multidimensional Scale Analysis -MSA- that works by associating items that are frequently placed within the same grouping and places them in a multivariate space, generating a graph or map that results from the interaction between the data of the interviewees, thereby creating associations or groups that define the categories constructed by the interviewees for the same event (PACHECO, 1996). These graphs are displayed as a three-dimensional picture that shows a distribution of points or numbers along its Cartesian space. These points or numbers can be seen scattered in small groups, large groups, or individually in most cases. A spatial relation or vicinity analysis and definition between points or numbers is carried out when the above occurs. And it is here, considering the criteria used by the interviewees, where we proceed to select the related groups and divide or partition, which results in the emergence of categories.

It is important to note that the division or partitioning are the researcher's judgment criteria, given his experience and expertise to interpret the closeness and similarity between items, and the description of the different classification categories provided by the interviewees, considering that an analysis and interpretation of the similarities in the concepts and categories produced by the individuals (teachers) is under way.

\section{Results}

The results obtained through the CMI interview allowed to define six type of categories for the study, which are regarded as the main conceptions of environment and EE recognized by the teachers participating in the study. Such declared conceptions and their respective degree of frequency were as the following: Nature (28\%), Environmental Impairment (22\%), Rurality (16\%), Sustainability (15\%), Conservation (11\%), and Subsistence (8\%) (Figure 1). We describe them below. 
Figure 1 - Main conceptions about environment and EE Multivariate scale as declared by teachers of rural DEI in Bogotá.

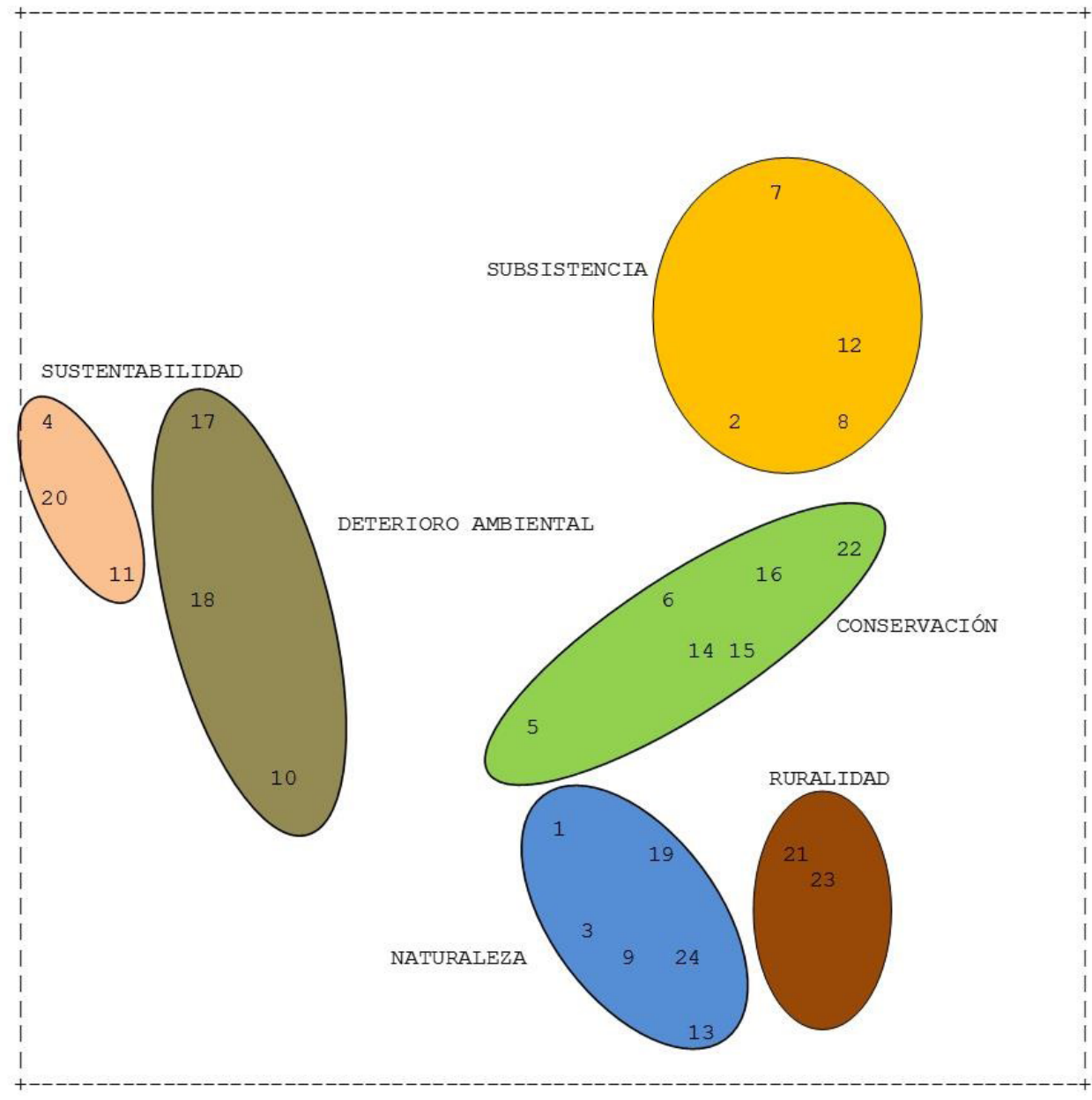

Source: Authors' own elaboration

This is the environment and EE concept with which teachers in the four rural DEI studied in Bogotá most identified with. The reason for this could be due to

the context in which teachers work is a geographical space widely surrounded by green areas, rich in endemic vegetation, trees and gardens, and in some cases small areas with crops. There are also forest reserve areas and protected forests for aquifers, which are very close to the institutions. Teachers often come to these places for trips or fieldwork with their students.

-Culturally, nature is traditionally ingrained driven family customs and social relationship, since the teachers stayed in touch with nature since childhood through trips or walks through places such as parks, mountains, lakes, rivers, etc., and these aspects 
are very peculiar to Colombian inhabitants.

-The link of some teachers with respect to their vocational training, which, in some cases, is related to the natural sciences.

-The curriculum structure in educational institutions that involves the environmental dimension in projects where all teachers, by institutional policy, include activities for children to interact with nature in their work plans.

\section{Environmental impairment:}

The reason that allowed to identify this conception is due to the following:

-Teachers understand about the biological, ecological, sociological and political problems faced by the region, the city, the country and the world regarding the environmental issue as a whole.

-Environmental problems are recognized as that aspect that somehow involve or have some impact on ecosystems and, in particular, on humanity, but it is not clear what causes them or how environmental problems actually arise.

-Environmental problems are mainly associated with issues like pollution, drought and loss of ecosystems. Nevertheless, aspects such as animal abuse, transgenics or habitat transformation (Nature-Built), which may account for other environmental problems situations, are seen as reflection, technology or development topics.

\section{Rurality:}

This idea is associated with the professional live of teachers, since their practices strongly influence rural education and agro-ecological training. The reasons that define this idea may be due to the following:

-Educational institutions' structure and curriculum content are designed to train students in agricultural and agro-industrial development and production issues.

-Teachers typically work in a context of countryside and agricultural production areas.

-The population of children and students attending school facilities comes from nearby houses or farms.

-Educational institutions approach the environmental dimension through projects that lead teaching activities towards agroforestry, agro-ecological and agricultural matters.

\section{Sustainability:}

The teachers defined this concept as the mechanism whereby natural resources are managed and exploited in a balanced way and without altering the biological and ecological rhythm of nature. This idea was defined according to the following:

-Sustainability is associated with, sustained development and sustainable devel- 
opment. For teachers, each word is a synonym of progress, growth, and both social and economic evolution. However, sustainability embraces this concept and broadens it with the need to think about a type of development that works for the well-being of our own and future generations.

-In rural areas, the issue of sustainability is thought of as the entrepreneurship and business creation actions that will promote a better quality of life in the countryside.

\section{Preservation:}

This is a protectionist idea that teachers permanently identified in their classifications given their interest in keeping natural spaces and their components intact or, at least, in optimal preservation levels for enjoyment and admiration. The arguments that constituted this idea are related to:

-There is basic and general knowledge by the teachers about natural sciences and ecology regarding the natural, biological and geographical elements of nature and the environment.

-The permanent ties of teachers with the countryside, the city and natural resources drive in them the need to think and work for the preservation and proper management of the environment and natural resources.

\section{Subsistence:}

It was identified by teachers as the mechanism that human beings have to maintain minimum and satisfactory living conditions. This idea was constituted according to the following:

-The countryside is thought to be the main food reserve for the city. If these did not exist, farmers, ranchers or the countryside itself, there would be no inputs and products to satisfy the demands of most societies.

- Educating and training children and young people to live and seize the benefits that the countryside offers means having productive citizens that guarantee the survival of others.

\section{Relationship between conceptions identified in teachers and approaches to EE}

We present a comparison between the conceptions declared and identified in teachers, and the approaches to concept analysis by the aforementioned model of TALERO, UMAÑA AND CHAVEZ (2000). According to Table 2, we found that the concepts described are related to the different approaches to EE. 
Table 2 - Concepts identified in teachers of the Rural DEI of Bogotá and their relationship with $\mathrm{EE}$ approaches.

\begin{tabular}{|c|c|c|}
\hline Concept's Approach in EA & Divisions by approach & $\begin{array}{l}\text { Declared and identified con- } \\
\text { ceptions }\end{array}$ \\
\hline \multirow{3}{*}{ Conceptual approach } & Physical-natural subsystem & Nature \\
\hline & Socio-cultural subsystem & Rurality \\
\hline & Subsystem created or built & Rurality \\
\hline \multirow[t]{4}{*}{ Philosophical approach } & & Environmental impairment \\
\hline & Aesthetic Value & $\begin{array}{l}\text { Nature } \\
\text { Preservation } \\
\text { Rurality }\end{array}$ \\
\hline & Green value & $\begin{array}{l}\text { Nature } \\
\text { Preservation }\end{array}$ \\
\hline & Economic value & $\begin{array}{l}\text { Subsistence } \\
\text { Sustainability }\end{array}$ \\
\hline \multirow[t]{4}{*}{ Axiological approach } & Humanistic value & $\begin{array}{l}\text { Nature } \\
\text { Rurality }\end{array}$ \\
\hline & Moral value & Preservation \\
\hline & Recreational Value & Preservation \\
\hline & Scientific value & Sustainability \\
\hline \multirow[t]{2}{*}{ Pedagogical approach } & & $\begin{array}{l}\text { Sustainability } \\
\text { Nature }\end{array}$ \\
\hline & Core activities & $\begin{array}{l}\text { Nature } \\
\text { Preservation } \\
\text { Environmental impairment }\end{array}$ \\
\hline \multirow[t]{2}{*}{ Didactic approach } & Ludic activities & Preservation \\
\hline & Goal-oriented activities & $\begin{array}{l}\text { Sustainability } \\
\text { Subsistence }\end{array}$ \\
\hline Political-legal approach & & Environmental impairment \\
\hline
\end{tabular}

Fuente: Source: Authors' own elaboration

Thus, the idea of Nature can be seen from a conceptual approach, given that teachers associate the natural with geographical, biological and ecological environments. Similarly, it appears in the axiological approach as an aesthetic value because the natural involves a physical and visual appeal for teachers; as an ecological value because it is the main element in the biological system; and finally, as a humanistic value because the natural suggests expressions of affectivity and gratification in teachers. It can be considered 
in the pedagogical approach given that teachers conceived natural systems as elements for learning, where the human being discovers and understands. Finally, the idea of Nature is addressed in the didactic approach as a core activity, since teachers considered that learning through the relationship with nature or other living beings stimulates the cognitive learning process and the creation of new knowledge.

Environmental Impairment appears in the Philosophical Approach as a form of expression by voicing concerns about the environmental state of the planet and the urgent needs to address it and seek solutions to solve it. Likewise, the Didactic Approach presents it as a core activity considering that environmental problems and the search for solutions promote new knowledge through activities such as scientific research and experimentation. Finally, the Political-Legal Approach addresses this concept bearing in mind that teachers constantly expressed the need to create, expand or improve rules that control and eradicate actions that attack the environment.

Rurality falls within the conceptual approach, socio-cultural system, taking into account that teachers regarded the rural context as a social form whose main stakeholder is the peasant and his lifestyle. On the other hand, the system created or built on the understanding that the countryside and the city interact socially and culturally in the life of the peasant falls within the same approach. It also appears as an aesthetic value in the axiological approach, considering that the rural has physical, natural and visual attractions that make it unique and different for teachers. Rurality falls within the same approach as a humanistic value, given that the countryside offers a variety of landscapes that stimulate emotional feelings and self-esteem in the human being.

Sustainability is related to the axiological approach as an economic value at first, considering that teachers think about the idea of sustainability as an economic development process beneficial to humanity. Finally, as a scientific value, considering that sustainable development starts from the implementation of new technologies and the generation of knowledge. In the same order, the Pedagogical Approach contemplates the concept of sustainability by considering it an environmental development strategy that generates new knowledge through scientific work. Lastly, for this concept, the Didactic Approach appears as an achievement-oriented activity that sees sustainability as a stimulant to scientific and exploratory creation.

For Conservation, two approaches were identified: the first has to do with the axiological approach and as an aesthetic value, since preserving nature and natural resources will ensure the enjoyment for future generations. On the other hand, as an ecological value, since it guarantees the presence of plant and animal species as a source of life; as a moral value under the understanding that conservation must be an ethical responsibility matter for the care of the environment; and as a recreational value because preservation ensures that natural settings for leisure and recreation are kept in good condition. The second Approach is didactic-related in its core activity, understanding that preservation can stimulate cognitive learning processes. As a ludic activity in the same way, because creative and artistic initiatives can be developed through preservation for the change of thought. 
Finally, Subsistence is framed within the axiological approach as an ecological value, given that teachers believe that human subsistence is dependent on the good relations between man and natural systems. From the Didactic Approach, as an activity-oriented achievement, bearing in mind that human subsistence depends on development and scientific capacity to guarantee access to food, services, etc.

\section{Relationship between the concepts identified in teachers and the currents about EE}

Since the previous concepts arose directly from the conceptual and cognitive work of teachers, it would be relevant for this research to conduct a comparative analysis between what was identified through teachers, and EE currents and concepts proposed by SAUVE (2010), given that methodologically these typologies were considered to choose the images and their subsequent use in the classification and construction of analysis categories process.

To study and assess the environmental component in the academic processes of educational institutions, SAUVÉ (2005) proposes a 15-current typology and 15 concepts to study EE, which constitute a theoretical reference that makes it easier to determine the field of action in which EE develops, and thus corroborate teachers' conceptual trends regarding environmental criteria. Below (Table 3) is a comparative matrix prepared to determine the relationship between the concepts identified by the teachers in the study, and the currents and EE concepts proposed by SAUVÉ (2005).

Table 3 - Concepts identified in the teachers of the Rural HEIs of Bogotá and their relationship with the currents and EE concepts by SAUVÉ (2005).

\begin{tabular}{cll} 
Concept identified by teachers & EE currents & EE Concepts \\
Nature & Naturalist & Nature \\
\cline { 2 - 3 } $\begin{array}{c}\text { Environmental impairment } \\
\text { Rurality } \\
\text { Sustainability } \\
\text { Preservation }\end{array}$ & Resolutive & Problem \\
\cline { 2 - 3 } Subsistence & Bio-regionalist & Place where of belonging \\
\cline { 2 - 3 } & Sustainability & Development \\
\cline { 2 - 3 } & Humanist & Resource \\
\hline
\end{tabular}

Source: Authors' own elaboration 
According to Table 3, it is observed, first of all, that the Nature Concept relates to the Naturalist Current and the Nature Conception of EE by Sauve. This is because the teacher's idea was built through concepts and assertions that the teacher makes of the man-nature relationship.

Meanwhile, for SAUVÉ (2005) the Naturalist idea is directly related to the natural and nature, a term that EE interprets as the knowledge of the various life forms and systems, the exploration of biodiversity, and the understanding of natural phenomena, and these aspects are similar in content to those described by teachers in their conceptions.

The second aspect is the Environmental Impairment Concept, which is included in the Resolutive Current and Problem Conception of EE proposed by Sauvé. The reasons that drove teachers to define this conception respond to statements related to human intervention in nature and the damage he has caused.

For SAUVÉ (2005), the concept of Environmental Impairment is not defined as an EE Conception per se, but rather as a component of the Problem Concept at a later stage (understood as more of a consequence). This differentiation justifies the separation of concepts between what teachers defined and what Sauvé proposed, since impairment can be both the final phase of a problem and the initial phase of other problems for the former or, failing that, the accumulation of different problems; while it is the identification of only one from its initial (cause) and final (effects) phase for the latter.

Third is the concept of Rurality, an aspect pertaining to the Bio-regionalist Current and the Concepción Place of belonging by SAUVÉ (2005). The teachers' conception was defined considering the importance of the countryside and the use of natural resources from the countryside in food production.

Sauvé defines Bio-regionalism as any geographical context with special characteristics where social and community interest projects can be developed. On the other hand, Sauvé's conception of Place of Belonging refers to the specific places for gathering and social development for productive work, stands that are very similar to those defined by teachers regarding Rurality. Nevertheless, there are marked differences because for teachers the Rural is vested with cultural and ancestral values associated with their lifestyle, which do not necessarily constitute productive processes such as Sauvé proposed.

In the fourth aspect, we find the concept of Sustainability, which belongs with the Sustainability Current and the Concept of Development of SAUVÉ (2005).

It describes Sustainability and development as technological strategies based on scientific and economic contributions to improve and guarantee a better quality of life for the human being in the future, aspects that are fully consistent with the definitions provided by the teachers.

The fifth aspect refers to the Preservation Concept, which relates to the Conservationist Current and the Concept of Resources of SAUVÉ (2005).

For this author, the Preservation Current and the Concept of Resource are linked to the way to adopt styles and behaviors that seek to maintain natural resources and nature in optimal state, an issue coinciding in many of the aspects stated by the teachers 
to define the Preservation Concept.

Finally, the Subsistence Concept is akin to the Humanist Current and the Livelihood Concept. This matter makes sense, as teachers are interested in thinking Subsistence as an environmental issue relating to needs and satisfactions, which the human being needs to address in order to attain an optimal quality of life.

However, for Sauvé, the Humanist matter makes sense in the way man relates to his environment and to the natural environment, while the Livelihood Concept refers to all those biophysical aspects (natural and constructed) and way of life (urban and rural) that humans need to be able to subsist, which differ given that teachers' view is less materialistic but individualistic and subjective with regards to tending to the basic needs of human survival, while Sauvé proposes a generalist view of the environment as one more element for human survival.

Based on the comparative analysis between Sauvé's proposals about EE currents and their respective definition of EE concepts, it is clear that in the rural context, as well as in other contexts, there may be differences of opinion regarding how people, in this case the teachers analyzed, relate and position their understanding of the environmental dimension based on their realities and needs.

\section{Conclusions}

The research allowed us to understand that the environment and the educational scenario in which the work of the teachers participating in the study is immersed influences their actions and educational practice. The cultural matter and life in the countryside were found to determine trends in teachers by promoting nature protection and social development educational actions. The study is relevant in that it ratifies that EE processes in educational institutions in rural contexts differ from those in urban contexts, because of the interest shown by educational stakeholders (institutions, teachers and students) to keep rural life models active and in harmony with nature.

From the point of view of the EE currents and conceptions of SAUVÉ (2005 and 2010) as a theoretical component to approach in educational scenarios, four of the general conceptions described by the teachers in the study were found to have some kind of conceptual relationship with his proposals. Thus, the concept Nature is akin to the naturalistic current or conception; environmental impairment to problem; sustainability to sustainability; and preservation to preservationist.

Among the conceptions declared by the teachers, we identified those of Rurality

and Subsistence that are not defined per se in Sauvé's EE currents and could be said to differ in some aspects such as the following:

(1) The concept of Rurality could be thought to pertain to a bio-regionalist current, where Sauvé proposes that this conception take into account all community development aspects. However, and not unaware that Rurality might be embedded in this aspect, it differs in other social and human-related issues regarding the lifestyle in the countryside in Colombia, the traditional and cultural recognition of the peasant or, as SERRANO 
and LÓPEZ (2012) put it, the "rural" as a different world and even the opposite of the urban. Not withstanding the foregoing, nowadays it is recognized as the livelihood that includes income generation from non-agricultural activities, greater ties among people and urban centers, new technologies and media that have narrowed the gap between the traditional city-countryside isolation, with the dissemination of values and customs previously considered exclusive to the urban environment modifying life in this setting, while facilitating the understanding of rural affairs. Colombia already sees Rurality as a continuum of territories with diverse and inhomogeneous characteristics in terms of basic services availability, economic and social development possibilities, population dispersion and concentration, State institutions presence and effectiveness, institutional development and ties with large urban centers.

(2) Similarly, the concept of Subsistence is not represented in Sauvé's EE currents per se, which might be thought to pertain to a humanist view, as livelihood, must be addressed as a mechanism by which human beings meet and satisfy their basic life necessities, which, according to MAX-NEEF (1994), correspond to a series of ontological (the being, having, doing and being) and axiological (identity, freedom, affection, recreation, among others) categories.

Finally, the study found similarities in the results in terms of the teachers' description of their thinking regarding the environmental issue (conceptions, representations and imaginaries). The relationships are given because the majority of studies defined similar analysis categories or because, taking up those proposed by SAUVÉ (2005 and 2010), the Naturalist, Preservationist and Problem currents predominate in most studies.

\section{References}

BARRIOS, A. Concepciones sobre ciencias naturales y educación ambiental de profesores y estudiantes en el nivel de educación básica de instituciones educativas oficiales del Departamento de Nariño. Rhec, 12 (12): 249-272. 2009.

CALAFELL, G. y BONIL, J. Identificación y caracterización de las concepciones de medio ambiente de un grupo de profesionales de la educación ambiental. Enseñanza de las Ciencias, 32 (3): 205-225. 2014.

DEMOLY, K.R.A. y SANTOS, J.S.B. Aprendizagem, educação ambiental e escola: modos de enagir na experiência de estudantes e profesores. Ambiente \& Sociedade, (21): 2018

FLOGAITIS, E. y AGELIDOU, E. Kindergarten Teachers. Conceptions about Nature and the Environment. Environmental Education Research, 9 (4): 461-478. 2003.

HOLLMAN, V. Imágenes y visualidades de la cuestión ambiental en la geografía escolar argentina. Huellas, 15: 51-71. 2011. 
LEÓN, J.; VALLEJO, C.; PARRA, A. y OBREGOSO, Y. Clasificación múltiple de ítems y las representaciones sociales sobre ambiente en profesores rurales. Actualidades Investigativas en Educación, 10 (2): 1-26. 2010.

MAX-NEEF, M. Desarrollo a escala humana. Montevideo: Nordan - Comunidad; 193 p. 1994.

MICHAIL, S.; STAMOU, A. y STAMOU, G. Greek Primary School Teachers' Understanding of Current Environmental Issues: An Exploration of Their Environmental Knowledge and Images of Nature, Science Education, 91: 244-259. 2007.

MUÑOZ, F; BOGNER, F; CLEMENT, P.; CARVALHO, G. Teachers' conceptions of nature and environment in 16 countries. Journal of Environmental Psychology, 29 (4): 407-413. 2009.

PACHECO, J. La clasificación múltiple de ítems y el análisis de escalogramas multidimensionales. Suma Psicológica. 3 (1), 25-37. 1996.

PÁRAMO, P. Etnografía rápida. En: P. Páramo (Editor). La Investigación en Ciencias Sociales: Estrategias de Investigación (p. 143-150). Bogotá: Universidad Piloto. 2011.

PEDROZO, R. y DE OLIVEIRO, P. Alfabetização visual para residuos sólidos: aprendizagem por interpretantes a partir da leitura de uma imagem inventiva de um estudante do curso técnico em química. En: Anais de la XVI Semana da Educação (p. 27-40). Londrina: Universidad Estatal de Londrina. 2015.

PERALES, J. Retos y dificultades para una educación ambiental informal. Alambique. (64), 2335. 2010.

QUIGLEYA, C.; MILlERB, Z.; DOGBEYC, J.; CHED, S.; y HALLO, J. No One Should Destroy the Forest: Using photo-based vignette interviews to understand Kenyan teachers' views of the environment. International Journal of Science Education, 36 (17): 2937-2957. 2014.

REZLER, M.; SALVIATO, G. y WOSIACKI, S. Quando a imagem se torna linguagem de comunicação de estudantes. Séries do ensino fundamental em Educação Ambiental. Enseñanza de las Ciencias, 8 (1): 304-325. 2009.

SAUVÉ, L. Uma cartografia das corrientes em educação ambiental. In: M. Sato y M. Carvalho (Coords). Educação Ambiental: pesquisas e desafíos (p. 17-44). Porto Alegre: Artmed. 2005.

SAUVÉ, L. Educación científica y educación ambiental: un cruce fecundo. Enseñanza de las Ciencias. 28 (1), 5-18. 2010.

SERRANO, J. y LÓPEZ, L. Manual para la formulación y ejecución de planes de educación rural: 
Calidad y equidad para la población de zona rural. Bogotá: MEM. 2012.

SULLIVAN, J. The use of photographs to portray urban ecosystems in six introductory environmental science textbooks. Journal of Research in Science Teaching; 45(9): 1003-1020. 2008.

TALERO, E.; UMAÑA, G. y CHÁVEZ, D. Capacitación de docentes universitarios en educación ambiental. Bogotá: MMA; 2000. 


\section{Carlos Julio Galvis-Riaño}

■ cgalvis2002@correo.ugr.es

ORCiD: https://orcid.org/0000-0001-8296-1232
Submitted on: 20/09/2018

Accepted on: 20/02/2020

2020;23: e02001

\section{Francisco Javier Perales-Palacios}

$\square$ fperales@ugr.es

ORCiD: https://orcid.org/0000-0002-6112-2779

\section{Yolanda Ladino-Ospina}

$\square$ yladino@pedagogica.edu.co

ORCiD: https://orcid.org/0000-0002-8820-1354

How to cite: GALVIS-RIAÑO, C. J.; PERALES-PALACIOS, F. J.; LADINO-OSPINA, Y. Conceptions about environment and environmental education by teachers from rural schools in Bogotá — Colombia. Ambiente \& Sociedade. São Paulo, v. 23, p. 1-20, 2020. 


\title{
Conceitos sobre meio ambiente e educação ambiental de professores de centros educacionais rurais de Bogotá - Colômbia
}

\author{
Carlos Julio Galvis-Riaño \\ Francisco Javier Perales-Palacios \\ Yolanda Ladino-Ospina
}

São Paulo. Vol. 23, 2020

Artigo Original

\begin{abstract}
Resumo: São caracterizar as concepções de Ambiente e Educação Ambiental (EA) de uma amostra de professores de quatro escolas rurais de Bogotá. As correntes EA (Sauvé, 2010) foram utilizadas como referencial teórico, aspecto considerado para a metodologia e análise de informações. Foram realizadas aplicando a Classificação de Múltiplos Itens, usando imagens da atualidade ambiental. $O$ intuito da entrevista foi avaliar a análise dos professores que foram orientados a realizar classificações de acordo com seus conhecimentos e experiências. Com base em suas próprias descrições, as classificações foram categorizadas na direção das correntes de EA. Com as informações obtidas, constatou-se que os educadores têm diferentes formas de abordar a questão ambiental e associá-la à sua prática educativa. Observou-se uma forte tendência em assumir que o ambiente e a EA são uma questão biológica e conservacionista, aspectos básicos para a vida no campo.
\end{abstract}

Palavras-chave: Educação ambiental, concepções de professores, ambiente, Classificação Multiple de Itens

Como citar: GALVIS-RIAÑO, C. J.; PERALES-PALACIOS, F. J.; LADINO-OSPINA, Y. Conceitos sobre meio ambiente e educação ambiental de professores de centros educacionais rurais de Bogotá - Colômbia. Ambiente \& Sociedade. São Paulo, v. 23, p. 1-20, 2020. 


\title{
Concepciones sobre ambiente y educación ambiental de profesores de centros educativos rurales de Bogotá - Colombia
}

\author{
Carlos Julio Galvis-Riaño \\ Francisco Javier Perales-Palacios \\ Yolanda Ladino-Ospina
}

São Paulo. Vol. 23, 2020

Artículo original
Resumen: Se caracterizan las concepciones de Ambiente y Educación Ambiental (EA) que llevó a cabo una muestra de profesores de cuatro colegios rurales de Bogotá. Se tomó como referente teórico las corrientes de EA (Sauvé, 2010), aspecto considerado para la metodología y análisis de información. Se realizaron entrevistas aplicando la Clasificación Múltiple de Ítems, empleando imágenes de la actualidad ambiental. Se buscó que los profesores realizaran clasificaciones de acuerdo con sus conocimientos y experiencias. Basados en sus propias descripciones, las clasificaciones fueron categorizadas en dirección con las corrientes de EA. Con la información obtenida se logró establecer que los educadores tienen diferentes formas de abordar la cuestión ambiental y de asociarla con su práctica educativa. Se observó una fuerte tendencia hacia asumir que el Ambiente y la EA son una cuestión biológica y conservacionista, aspectos básicos para la vida en el campo.

Palabras-clave: Educación ambiental, concepciones del profesor, ambiente, Clasificación Múltiple de Ítems.

Como citar: GALVIS-RIAÑO, C. J.; PERALES-PALACIOS, F. J.; LADINO-OSPINA, Y. Concepciones sobre ambiente y educación ambiental de profesores de centros educativos rurales de Bogotá - Colombia. Ambiente \& Sociedade. São Paulo, v. 23, p. 1-20, 2020. 